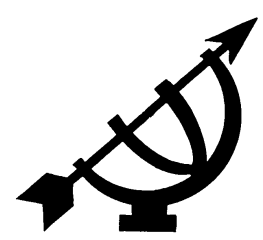

\title{
'n Kennis anders as die bloot analitiese? Die Westerse denkwyse versus dié van die Ooste en Afrika
}

\author{
B.J. van der Walt \\ Skool vir Filosofie \\ Potchefstroomkampus \\ Noordwes-Universiteit \\ POTCHEFSTROOM \\ E-pos: hannah@intekom.co.za
}

\begin{abstract}
Knowledge different from merely the analytical? The Western way of thinking versus the Eastern and African mode of thought

This study addresses the problem of intercultural contact and communication from the angle of the different ways of thinking in the West, the East and Africa. As an introduction, the author explains his own viewpoint about culture and worldview as well as how culturalworldviewish differences should be evaluated. In the first main section the Western mode of thought is contrasted with both ancient Hebrew thinking and that of the modern Japanese. This is followed by an analysis of the differences between the thought patterns of the Western mind and that of the (traditional) African. The study reveals remarkable similarities between the contours of thinking in the East and Africa in contrast with that of the West. In conclusion, the distilled theoretical (cultural-philosophical) insights are applied practically to the educational situation (secondary as well as tertiary) on the African continent.
\end{abstract}

\section{Opsomming}

'n Kennis anders as die bloot analitiese? Die Westerse denkwyse versus dié van die Ooste en Afrika

Die vraagstuk van interkulturele kontak en kommunikasie word in hierdie artikel bespreek vanuit die hoek van die verskillende denkwyses van die Weste, die Ooste en Afrika. Ter inleiding word die skrywer se eie vertrekpunte oor kultuur, lewensvisie en die evaluering van kultureel-lewensbeskoulike verskille gestel. In die eerste hoofafdeling word die denkwyse van die Weste gekontrasteer met dié 
van sowel die antiek-Hebreeuse as die moderne Japannese. Dit word gevolg deur ' $n$ analise van die verskillende denkpatrone van die Weste en (tradisionele) Afrika. Uit die ondersoek blyk onder andere dat daar merkwaardige ooreenkomste is tussen die denkkontoere van die Ooste en Afrika teenoor dié van die Weste. Ten slotte word die teoretiese (kultuur-filosofiese) insigte prakties op die (sekondêre en tersiêre) onderwys van die Afrikakontinent toegepas.

\section{Inleiding: Opset}

In die inleiding word agtereenvolgens die probleem gestel, 'n voorbeeld ter illustrasie daarvan gegee, gesuggereer wat die oplossing kan wees, die bronne waarop die studie gebaseer is word genoem en ten slotte word daarop gewys dat, aangesien hierdie 'n onderwerp is wat uiteenlopende benaderings toelaat, dit wenslik is dat die skrywer sy eie vertrekpunte uitspel.

\subsection{Die probleem}

Mense van die Westerse kultuur (vir wie hierdie artikel in die eerste plek bedoel is) ontmoet in Suid-Afrika byna daagliks en op verskillende lewensterreine ander mense wie se lewe tot 'n groot mate bepaal word deur óf die Afrikakultuur óf die kultuur van die Ooste. As gevolg van die kultuurverskille kan daar op die volgende drie vlakke probleme ontstaan:

- op kognitiewe vlak (hoe mense dink) kan dit lei tot misverstande;

- op gevoelsvlak (die affektiewe) kan dit aanleiding gee tot gevoelens van meerderwaardigheid teenoor mense van 'n ander kultuur;

- op die vlak van waardes (die evaluatiewe) kan (onnodige) veroordeling van mekaar plaasvind.

Aan die een kant is dié verskynsels normaal. Soos 'n Afrikaspreuk dit stel: "As jy nog nooit iemand anders as net jou eie ma se kos geëet het nie, sal jy altyd dink (al is sy 'n hopelose kok) dat haar kos die beste is.".

Aan die ander kant is dit egter waar dat iemand wat selfs net een keer die voorstoep van sy eie huis (kultuur) verlaat het, wyser is as die persoon wat dit nog nooit gewaag het nie. lemand wat geen ander kultuur as sy eie ken nie, ken ook nie werklik sy eie kultuur nie - ten minste nie op 'n kritiese manier nie. Kennis van ander kulture beteken nie noodwendig dat 'n mens jou eie kultuur minag of verwerp nie, maar eerder dat 'n mens dit beter verstaan en 
waardeer. Die basiese oortuiging waaruit hierdie artikel geskryf is, is dat kultuurverskeidenheid nie as 'n bedreiging nie, maar as 'n verryking beskou moet word. Die probleme wat aan interkulturele kontak verbonde is word dus nie negatief beskou nie, maar positief - as 'n uitdaging. Anders gestel: die probleme lê nie primêr by kultuurverskeidenheid as sodanig nie, maar by die wyse van evaluering.

\section{2 'n Voorbeeld ter illustrasie van die vraagstuk}

Om die probleme waaroor die ondersoek handel konkreter te maak, word kortliks verduidelik hoe kommunikasie in die Afrikakultuur plaasvind. (Soos sal blyk, is dit ook die geval in die Ooste.)

Behalwe dat Afrikane (as gevolg van hulle tradisionele mondelinge kultuur) eerder persoonlike kommunikasie as onpersoonlike, geskrewe oordrag van inligting verkies (vgl. Klem, 1982), verkies hulle ook eerder indirekte as direkte kontak.

O'Donovan (2000:8) verduidelik dit soos volg:

If the issue is sensitive, the two parties may even employ a mediator to carry opinions back and forth in order to avoid direct encounter. There is an underlying assumption that to be direct or confrontational where there is differences of opinion may lead to a broken relationship between the two persons. By contrast, it is typical in the West for people to state their opinions or feelings on a matter openly and plainly. They will even go further and argue their position vigorously to change the opinion of the others present. The relationship seems to be secondary to the goal of changing the other person's mind.

Van der Walt (2000:28-29) verduidelik verder dat, as gevolg van Afrika se hoflikheids- en skaamtekultuur ('n persoon mag nie - veral nie in die openbaar nie - tot skande gemaak word nie), goeie persoonlike verhoudinge vir Afrikane soms belangriker is as die waarheid. Veral ten opsigte van buitestaanders en vreemdelinge, is die mense van Afrika gereserveerd en versigtig. Daarom sal hulle selde 'n stellige antwoord op 'n vraag gee. Hulle sal eerder sê hulle sal daaroor dink of selfs bevestigend antwoord, terwyl hulle eintlik "nee" moes gesê het.

Hierdie vermoë om rondom die punt te draai sonder om duidelik te sê wat jy dink - natuurlik tot groot frustrasie van reguit Westerlinge word deur Afrikane as selfbeheersing en intelligensie beskou. Die begrip intelligensie beteken hier dus iets soos bedagsaamheid, 
omsigtigheid, wysheid, skranderheid of slimheid. Dit word as 'n deug beskou wat 'n mens in staat stel om in die ingewikkelde netwerk van sosiale verhoudinge te kan oorleef. (Afrika dink kommunalisties en is gesteld op menseverhoudinge.) Vir Westerlinge lyk so iets egter na veinsery, sluheid, leuenagtigheid en bedrieëry. Maar is dit 'n korrekte evaluering?

Vir die meeste Westerlinge lyk so 'n evaluering korrek - dit word ook deur hulle Christelike geloof bevestig. God verbied tog self in die negende gebod uitdruklik leuens en valse getuienis. Die Christelike tradisie mag, op die keper beskou, egter nie gelykgestel word met dié soort Westerse eerlikheid waar 'n persoon iemand anders prontuit "die waarheid vertel", sonder om die gevolge daarvan in ag te neem nie. Die boek Spreuke (bv. 18:2 en 15:11) sê dat net 'n dwaas alles sê wat in sy gedagtes opkom. Ook die Nuwe Testament leer ons dat die waarheid in liefde meegedeel moet word (Ef. 5:14; Kol. 4:6). 1 Korintiërs 13 leer dat die liefde - wat belangriker as die waarheid is - wel oor die waarheid verheug is (vers 6), maar ook baie dinge bedek (vers 7). Dieselfde boodskap word herhaal in 1 Petrus 4:8.

Hierdie een voorbeeld maak 'n mens daarop attent hoe kompleks kultuurverskille kan wees en hoe maklik hulle tot ernstige misverstande kan lei. Oplossing van verskille is nie eensydige veroordeling nie - God se openbaring kan 'n belangrike bydrae lewer tot 'n meer gebalanseerde standpunt.

\subsection{Die oplossing}

Die oplossing is voor die hand liggend. Om kommunikasieprobleme op kognitiewe vlak reg te hanteer, moet 'n mens verstaan dat mense van ander kulture verskillend as jyself dink. 'n Mens moet weet hoe ander mense (logies) dink, maar ook hoe hulle tot kennis kom. Om analities te redeneer is byvoorbeeld net één van die baie maniere om die werklikheid te verstaan.

\subsection{Beskikbare bronne oor die probleem}

Sowel die antropologiese as psigologiese studies wat met die oplossing van hierdie soort probleme kan help, het beperkings.

- Antropologiese studies fokus gewoonlik op die sogenaamde rasionaliteit van die "primitiewe" denke. Daar word aangetoon dat die primale denke (van bv. die Ooste en Afrika) wel nie dieselfde as die Westerse rasionele denke is nie, maar dat dit tog 'n eie soort "rasionaliteit" openbaar. Antropoloë soos Jarvie en Agassi 
(1970) en Winch (1970), probeer byvoorbeeld met 'n verruimde begrip van rasionaliteit aan te toon dat kulture soos dié van Afrika en die Ooste ook "rasioneel" is en daarom nie minderwaardig is teenoor die Weste nie. Magiese praktyke is byvoorbeeld effektief en daarom "redelik".

Die oplossing is myns insiens nie om paternalisties vanuit die Westerse hoek die primale denkwyses "rasioneel" te probeer maak nie, maar eerder om te erken dat dié denkwyses anders is en daarom vas te stel hoe hulle van die Westerse denkwyses verskil. In die Weste is daar deur die eeue baie betekenisse aan "rasioneel"/"redelik" gegee. (Dit het by die antieke Grieke begin, met die logiese soeke na die absoluut goeie en het uitgeloop op die ekonomies gedrewe tegnies-wetenskaplike rasionaliteit van vandag.) Christene behoort krities te staan teenoor die sekulêrWesterse rasionaliteitsidee (vgl. Klapwijk, 1983 en ander wat waardevolle kritiek vanuit Reformatoriese hoek gelewer het).

- Studies op die gebied van die (kognitiewe) psigologie lewer ook 'n bydrae op die gebied, maar hou twee probleme in. In die eerste plek is hulle vertrekpunte eng psigologies. Die breë kulturele agtergronde wat 'n beslissende invloed het op die denkwyse van mense, word nie in berekening gebring nie. In die tweede plek is die meeste psigologiese toetse om die kognitiewe vermoë te toets ook vanuit 'n Westers-kulturele perspektief opgestel, sodat hierdie toetse, streng gesproke, nie op mense van die Ooste en Afrika toegepas kan word nie.

Hierdie artikel het, sonder om die antropologiese en psigologiese ondersoeke se bydraes te ontken, eerder die karakter van 'n breëre kultuur-filosofiese aanpak. Aangesien die skrywer, sowel as die meerderheid eventuele lesers, met die Westerse kultuur vertroud is, word vanuit 'n Westerse hoek eers na die Ooste en dan na Afrika gekyk.

\subsection{Vertrekpunte}

My eie visie waaruit die probleem benader word, handel oor wat kultuur en lewensvisie is en hoe kulture (op verskeie vlakke) geëvalueer behoort te word.

\subsubsection{Kultuur as antwoord}

Elke kultuur - nie net die Christelike kultuur nie - is 'n respons op God se skeppingsopenbaring (vgl. Onvlee, 1973:263-282 en Van der Walt, 2001:12-19). As 'n inherent religieuse wese, kan die mens 
nie anders nie as om te antwoord op basiese vrae oor sy verhouding met God, sy medemens, die natuur en homself. As gevolg van die mens se sonde, is verskillende kulture egter geneig om sekere van hierdie basiese verhoudings te oorbeklemtoon. Die Westerse individualisme verabsoluteer byvoorbeeld die verhouding tot die self, terwyl die Afrikakommunalisme die gemeenskap oorbeklemtoon. Die ander drie verhoudinge word ook skeefgetrek, omdat hulle gesien word in die lig van die een verabsoluteerde verhouding (vgl. Van der Walt, 2001:17-19). In die verskillende antwoorde op verhoudingsvrae lê dus die mees basiese rede vir kultuurverskeidenheid.

Kultuur is iets wat oorgedra en aangeleer word en niemand verander maklik sy kultuur nie. Tog is kultuur nie staties nie. Dit word deur uiteenlopende faktore - ook ander kulture - beïnvloed. Geen kultuur is dus heeltemal homogeen nie - dit bestaan meestal uit subkulture. Dit beteken egter nie dat dit onmoontlik is om sekere algemene trekke by 'n kultuur vas te stel nie.

\subsection{2 'n Definisie}

Hiebert (1998:171) beskryf kultuur tereg as "systems of belief and practices that are built upon the implicit assumptions that people make about themselves, about the world around them and about ultimate realities".

In sy omskrywing van wat kultuur behels, kom drie basiese dimensies na vore: die kognitiewe (kennis), die affektiewe (gevoel) en die evaluatiewe (waardes). Hiebert (1998:30) sê:

We will define culture as the more or less integrated system of ideas, feelings and values and their associated patterns of behaviour and products shared by a group of people who organize what they think, feel and do.

Die mees fundamentele oortuigings wat 'n kultuur op hierdie drie vlakke bepaal, is vervat in 'n persoon of groep se lewensvisie. Hiebert (1998:45-49) toon tereg aan dat iemand se lewensvisie (worldview) die hart van sy kultuur is. Hierdie lewensbeskoulike uitgangspunte word deur mense as vanselfsprekend aanvaar en dus selde eksplisiet gemaak. Wanneer die lewensbeskoulike "bril" egter nie meer goed kan sien nie - sin maak van die werklikheid nie word dit "skoongemaak" of vervang. Mense glo dat die werklikheid is soos wat hulle lewensbeskoulike bril dit kleur.

Samevattend sê Hiebert (1998:47, 48): 
Taken together, cognitive, affective and evaluative assumptions provide people with a way of looking at the world that makes sense out of it, that gives them a feeling of being at home, and that reassures them that they are right. This world view serves as the foundation on which they construct their explicit belief and value systems, and the social institutions within which they live their daily lives.

Visueel voorgestel, sou 'n mens kultuur dus met konsentriese sirkels kon voorstel. Die binneste, diepste sirkel is die religieuse gerigtheid; die tweede is die lewensvisie (met die reeds genoemde drie vlakke); daarna volg al die dinge (geestelike en materieel) wat die mens tot stand bring (taal, instrumente, strukture); die heel buitenste laag is die sigbare gedrag en gewoontes.

\subsubsection{Die kognitiewe faset}

Aangesien hierdie studie handel oor hoe mense dink, val die fokus op die kognitiewe faset van die lewensvisie. Volgens Hiebert (1998:30) handel dié faset oor wat werklik is en wat nie. Dit gaan dus oor die kategorieë waarvolgens 'n bepaalde kultuurgroep die werklikhede (God, mens, medemens, natuur en norme) "sorteer", hulle verhoudings bepaal en in 'n oorsigtelike sisteem saamvat. In hierdie opsig bestaan groot verskille tussen die kulture.

\subsubsection{Evaluering}

In ooreenstemming met die voorafgaande, vind evaluering van 'n ander kultuur op drie vlakke plaas. Op die kognitiewe vlak gaan dit daaroor of die ander kultuur waar of vals is. Op die affektiewe vlak word dit goed- of afgekeur. Op die evaluatiewe vlak word geoordeel of dit reg of verkeerd is. Evaluering op elk van die drie vlakke hou sy eie gevaar in (vgl. 1.1).

- Op kognitiewe vlak kan misverstand ontstaan. Dit sluit 'n mens se misverstaan van ander se manier van dink sowel as ander se misverstaan van jou kultuur in (vgl. 1.2). Om sulke misverstand te verhoed, is dit belangrik om jou eie kultuur op 'n afstand te bekyk (vgl. Hiebert, 1998:92, 93). Antropoloë onderskei gewoonlik tussen 'n "emic" en "etic" verstaan wat mekaar moet komplimenteer. Hiebert verduidelik: "The former is needed to understand how people see the world and why they respond to it as they do. The latter is needed to compare one's culture with other cultures and test its understandings of the world against reality" (Hiebert, 1998:97). 
- Affektiewe evaluering het met handel te make. Entnosentrisme (bv. Eurosentrisme of Afrosentrisme) is gewoonlik die normale, maar verkeerde emosionele reaksie van mense wanneer hulle met 'n vreemde kultuur gekonfronteer word. Hulle het die gevoel dat hulle eie kultuur "normaal" en "beskaafd" is, maar nie die vreemde kultuur nie.

- Op die derde, evaluatiewe vlak speel waardes 'n nog belangriker rol. Hier is die groot gevaar 'n voortydige veroordeling van ander kulture - voordat 'n mens hulle nog leer ken en waardeer het.

As gevolg van die sondigheid van die mens, bestaan daar geen volledige goeie kultuur nie - ook nie die "eie" nie. As gevolg van God se algemene genade is daar egter ook geen totaal korrupte of bose kultuur nie. Geen kultuur mag dus onkrities veridealiseer of oorkrities verwerp word nie. Elke kultuur neig om iets wat inherent goed is te oordryf, sodat dit skeef ontwikkel. 'n Mens sal dus, veral op wetenskaplike terrein, moet leer om in elke kultuur die goeie, die minder goeie en die slegte te onderskei (vgl. Van der Walt, 2001:99). Tereg sê O'Donovan (2000:15):

No culture is best. No culture is right in everything. There are things in every culture that must be rejected by the sincere Christian because they are not pleasing the God. There are also beneficial things which can be learned from every culture.

Hiebert (1998:104) onderskei in dié verband tussen die goeie, die neutrale en die verkeerde elemente van 'n kultuur:

- In elke kultuur is daar baie dinge wat die moeite werd is en dus nie net behou nie, maar ook aangemoedig moet word (bv. sekere kulture se klem op goeie menseverhoudinge).

- Baie dinge in 'n kultuur is "neutraal" en hoef nie verander te word nie (bv. die verskillende maniere waarop huise gebou word of mense hulleself klee).

- Omdat alle mense sondig is, is daar egter ook dinge wat duidelik verkeerd en selfs sondig is en wat behoort te verander (byvoorbeeld menseoffers, verbranding van weduwees of ' $n$ onderdrukkende kastestelsel).

\subsection{5 'n Derde weg}

In hierdie benadering word sowel monokulturalisme as kulturele relativisme verwerp om 'n derde weg te volg. 
Dit is onmoontlik om met hierdie vertrekpunte langer monokultureel (etnosentries) te dink. Die eie kultuur is nie die enigste ware en universele norm waaraan ander kulture gemeet moet word nie.

Kulturele relativisme, wat leer dat alle kulture ewe waar is, is ook nie 'n oplossing nie, want as alle kulture ewe waar is, is kritiese evaluering in beginsel uitgesluit. Konsekwente relativisme is nie moontlik nie.

Die enigste uitweg ('n derde weg) is om in die lig van God se openbaring in die Skrif na transkulturele evalueringsnorme te soek (vgl. Hiebert, 1998:103). Dit is dus nodig om duidelik tussen die Christendom en God se Woordopenbaring te onderskei. Die Christelike geloof (as antwoord op God se Woord) verskyn self in verskillende kulturele gestaltes. Dit kan nie anders nie, want sonder 'n relatiewe kontinuïteit tussen 'n bepaalde kultuur en God se skeppingsopenbaring, sal God se Skrifopenbaring nie relevant wees nie. Aan die ander kant bestaan egter as gevolg van die mens se sonde radikale diskontinuïteit tussen elke kultuur en die Woord van God - anders was reformasie nie noodsaaklik nie.

In die soeke na sogenaamde "trans"-kulturele norme (Hiebert) sal daar met groot omsigtigheid te werk gegaan moet word, omdat ook die $\mathrm{Ou}$ en die Nuwe Testament in bepaalde kulture (die OudOosterse en Hellenistiese kulture) gewortel is. Die tydsgerigte vorm wat die evangelie destyds aangeneem het, mag nie tot universele, tydlose norm verhef word nie. Alleen die noukeurige bestudering van die Skrif kan die universele, blywende norme ontbloot (byvoorbeeld die liefdesgebod in sy verskillende gestaltes).

Nadat die vertrekpunte verduidelik is, kan die probleem van kultuurverskeidenheid in die lig daarvan ondersoek word.

\section{2. 'n Vergelyking tussen die denkwyse van die Weste en die Ooste}

Vir Suid-Afrikaanse Westerlinge is die Oosterse die minder bekende kultuur en daarom sal dit die breedvoerigste behandel word. Omdat die Oosterse denkwyse soveel ooreenkomste met die tradisionele denkwyse van Afrika vertoon, sal die Afrika manier van dink daarna slegs kortliks behandel word.

Altwee hierdie denkwyses is belangrik. Hoewel die Westerse denkwyse tans ten opsigte van wêreldwye invloed, die dominante is, is die denktrant van die Ooste en van Afrika bevolkingsgewys die 
oorheersende. Ook in Suid-Afrika is die twee denkwyses verteenwoordigend van 'n veel groter groep mense as die Westerse (hoofsaaklik blanke) bevolking.

In hierdie afdeling word op twee Oosterse kulture gefokus. Aangesien die bakermat van die Westerse denke die antieke Griekse kultuur is, begin dit met 'n vergelyking tussen die Griekse en die Hebreeuse kultuur. (As voorbeeld van die Oosterse denke, is die Semitiese denke ook belangrik, omdat dit 'n neerslag vind in die Ou Testament en vermeng met die Hellenisme, ook in die Nuwe Testament.) Om die kontinuïteit van die Oosterse denkmentaliteit tot op die hede duidelik te maak, word ook 'n tweede Oosterse kultuur, die Japannese, betrek.

\section{1 'n Vergelyking tussen die Westerse en die Oud-Oosterse denke volgens Boman (1968)}

In Die Untergang des Abendlandes (1922/1923) het Spengler reeds belangrike navorsing gedoen om die tipiese trekke van die Westerse denke te belig. Die klassieke werk van Boman (1968, 5e druk) Das hebraïsche Denken im Vergleich mit dem griechischen word in hierdie artikel as vertrekpunt geneem. Ook uit die werk van Wilson (1997) word belangrike addisionele gegewens geneem.

- Die Griekse en Hebreeuse kulture se werklikheidsvisies verskil duidelik. Eersgenoemde fokus op die dinge wat bestaan (die ontologiese), terwyl laasgenoemde ingestel is op die veranderende gebeure (die historiese) (Boman, 1968:182). Die Griekse denke is dus meer staties en die Hebreeuse meer dinamies (vgl. Boman, 1968:18-44).

- Die Griekse kultuur word getipeer deur logiese denke, terwyl die Hebreeuse gekarakteriseer word deur psigiese verstaan. "Das griechische Denken ist klares, logisches Erkennen, das israelitische ist tiefes, psychologisches Verstehen" (Boman, 1968:179). Hiermee word bedoel dat die saaklike, objektiewe kennis van dinge (synde) vir die Griek belangrik is en insig in die persoonlike, subjektiewe gevoelens en verhoudinge vir die Jood.

- Boman $(1968: 176,177)$ beskou die antieke Grieke as oogmense (sien/aanskoue is belangrik), terwyl die Hebreërs oormense was (gehoor is die belangrikste). Uit sy uiteensetting blyk egter dat hy met "sien" by die Grieke nie fisiese sien nie, maar intellektuele of teoretiese aanskoue (deurgronding) bedoel. Dit blyk ook uit sy uiteensetting dat nie net die ouditiewe nie, maar ook die visuele 'n rol in die Semitiese denke speel. 
- Uit die voorafgaande is dit duidelik waarom die Griekse denke deur Boman as abstrak teenoor die meer konkrete Hebreeuse denke getipeer word (vgl. Boman, 1968:172). Die Hebreeuse denke is volgens hom baie nader aan die werklikheid as die "bloedlose" Griekse denke. In hedendaagse Westerse terminologie, sou gesê word dat die Hebreeuse denke "voorwetenskaplik" is. Hierdie is myns insiens een van die belangrikste verskille. In die huidige Westerse wetenskaplike denke sou ten minste tussen die volgende ses soorte abstraksies onderskei kon word: (1) die abstrahering van die wette wat vir die natuur en die norme wat vir die mens geld; (2) die abstahering van die universele of algemene van die individuele gevalle; (3) die beklemtoning van 'n (onder)deel, wat as simbool (metafoor) vir die geheel dien; (4) die losmaak van 'n aspek (bv. die ekonomiese of die fisiese) uit die noue samehang van al die verskillende aspekte van die werklikheid; (5) die uitlaat van nie direk relevante detail van die komplekse struktuur van die werklikheid; (6) die uitskakeling van persoonlike en ander voordele en belange.

- Verder tipeer Boman (1968:178) die Griekse denke as sinteties, teenoor die Hebreeuse as analities. Dié tipering is nogal 'n verrassing, omdat konkrete denke meer holisties-sinteties ingestel is, terwyl abstrakte denke geneig is om 'n verskynsel in sy onderdele te analiseer. Uit Boman (1968:178-179) se verduideliking blyk egter dat hy met "analities" iets anders as die gewone betekenis van die begrip in gedagte het. Hy bedoel daarmee dat die Hebreeuse denke na die wesenlike (die kern of werklike "punt") van 'n saak of probleem soek en nie soos die Grieke, na bewyse nie. Die sentrale "punt" word vanuit verskillende hoeke by herhaling beklemtoon. (Dit is ook iets tipies van die Afrikadenke.) Daarom vergelyk Boman die Griekse denke met die argitektuur: die huis word stap-vir-stap opgebou. Vir die Hebreeuse denke is die metafoor van musiek meer gepas: dieselfde begintema keer in steeds nuwe variasies telkens in die musiekstuk terug.

- In ooreenstemming met die voorafgaande, verskil ook die waarheidsbegrip (vgl. Boman, 1968:177, 178). Vir die Griek is waarheid die regte (teoretiese) kennis en vir die Hebreër is dit die regte (praktiese) handelinge. 'n Mens kan dus verstaan waarom die kennisleer (epistemologie) in die Westerse denke nog altyd so belangrik was, terwyl vir die meeste Oosterlinge die regte morele optrede (die etiek) veel belangriker is. 
- Ten slotte gee Boman (1968:104-132) ook heelwat aandag aan hoe verskillend oor tyd en geskiedenis gedink is. Vir die Grieke was tyd iets siklies van aard en, omdat die geskiedenis niks nuuts opgelewer het nie, onbelangrik. Die Hebreërs se tyds- en geskiedenisvisie was egter liniêr. Tyd en die regte gebruik daarvan was vir hulle baie belangrik.

Afsluitend beklemtoon Boman (1968:179, 182) tereg dat albei hierdie denkwyses nodig is indien 'n mens in voeling met die (hele) werklikheid wil wees.

\section{2 'n Vergelyking tussen die Westerse en Oosterse denkwyse volgens Wilson}

\subsection{1 'n Bevestiging}

Die meer resente werk van Wilson (1997) bevestig verskillende aspekte van Boman se analise van die Hebreeuse denke:

- Dit is dinamies (Wilson, 1997:137).

- Dit is psigies: "The Hebrews were a very passionate people, they did not hide or suppress their emotions" (Wilson, 1997:139).

- Dit is relasioneel: "For the Hebrews, personal relationships have always been far more expressive of religious faith than mere intellectual assent to abstract statements or religious ideas" (Wilson, 1997:138).

- Dit is konkreet: "The Hebrews liked the concrete and tended to avoid the abstract" (Wilson, 1997:138).

- Dit is holisties en nie analities nie (Wilson, 1997:141).

- Dit is visueel-georiënteerd. Hebreeus is 'n baie kleurvolle, maar nie analities-presiese taal nie. Verhale was (net soos in Afrika) dus belangrik. "Theirs was primarily a description of what the eye sees rather than what the mind speculates" (Wilson, 1997:145).

- Boman se beskrywing van die Hebreeuse idee oor waarheid word ook deur Wilson (1997:136) bevestig: "For them truth was not so much an idea to be contemplated as an experience to be lived". Geloof is nie gesien as die intellektuele aanvaarding van sekere proposisies nie (die Westerse idee), maar om te doen wat reg is (vgl. Wilson, 1997:187).

- Ten slotte bevestig Wilson (1997:161) ook Boman se tipering van die Hebreeuse visie op die tyd en geskiedenis: 
Unlike some of their neighbors, the Hebrews did not hold to a circular view of history tied closely to the cycles of nature. Hebrew history was not a monotonous, purposeless, and eternal cycle of happenings. Nor did the Hebrews view life as a race towards death in which one desperately seeks to escape from the clutches of time ... Rather, in sharp distinction, the Hebrew view of time and history was essentially linear, durative, and progressive. In short, it was going somewhere, it was en route to a goal ...

Tyd is as iets besonder waardevol beskou wat reg gebruik moes word. "The Hebrew taught the world to sanctify time. They believed that something sacred was at stake in each event and each life. Hence one must not kill time but redeem it. Ephesians 5:16" (Wilson, 1997:162).

Wilson bied egter ook addisionele insigte oor die Hebreeuse denkwyse, waaronder die volgende:

\subsection{2 'n Holistiese geloof}

Vir die Hebreërs was godsdiens nie iets afgesonderd van die res van hulle lewe nie. Hulle het nie die Westerse onderskeid en selfs skeiding tussen die profane en sakrale geken nie. Die héle lewe was vir hulle religie (vgl. Wilson, 1997:156-159). In die hele wêreld moet God gedien word en nie net in die sielelewe nie (vgl. Wilson, 1997:176). Wilson (1997:176) stel dit soos volg:

Westerners often define spirituality as denying oneself, being detached from earthly concerns, and being intent on otherworldly values. By contrast, the Hebrews experienced the world of the spirit as robust, life-affirming, and this-worldly in character. ... Socalled spirituality did not come by negating or withdrawing from the world. Instead, they affirmed creation by finding a sense of holiness in the here and now. There was no division between the sacred and secular areas of life. It was all God's world, and it was to be enjoyed without a sense of shame or guilt.

\subsection{3 'n Kommunalistiese mensvisie}

Anders as vir die moderne Weste was nie die individu nie, maar die gemeenskap vir die Hebreërs die belangrikste. Wilson beskryf dit met die begrip "corporate personality" en verduidelik: "... the individual was always thought of as the collective (family, tribe, nation) ... This corporate personality was enforced by the fact that the entire community (past ancestors and future members) was viewed as one personality, 'a living whole' ..." (Wilson, 1997:187). 
Geloof en vroomheid is nie as iets apart van die gemeenskap gesien nie. Hierin kom die Oosterse denke weereens sterk ooreen met dié van Afrika.

\subsubsection{Blok-logika}

Omdat die denkwyse verskil, verskil ook die logika van die Grieke en Hebreërs. Volgens Wilson gebruik die Grieke 'n "stap"-logika. Daarvolgens redeneer ' $n$ mens vanaf 'n premisse (vertrekpunt) na 'n uiteindelike konklusie, terwyl elke volgende stap in die proses op 'n rasionele, logiese manier met die vorige saamhang. Die finale konklusie bevat net één aspek van die werklikheid. 'n Mens sou dit ook 'n óf-óf-logika kan noem: iets is óf waar óf vals.

In teenstelling hiermee noem Wilson die Hebreeus-Oosterse logika 'n "blok"-logika. Daarin kan gelyktydig verskillende perspektiewe en konklusies voorkom. (Ek sou dit 'n én-én-logika noem.) Wilson (1997:150) beskryf hierdie ander soort logika soos volg:

... concepts were expressed in self-contained blocks of thought. These blocks did not necessarily fit together in any obvious rational or harmonious pattern ... This way of thinking created a propensity for paradox, antinomy, or apparent contradiction, as one block stood in tension - and often illogical relation - to the other ... It is particularly difficult for Westerners ... to piece together the block logic ...

Wilson gee talle voorbeelde hiervan uit die Bybel. Dit is heelwaarskynlik ook hoe die Afrikalogika lyk.

\subsubsection{Indirekte kommunikasie}

Veral wanneer sensitiewe, belangrike sake ter sprake is, vind by Semiete nie regstreekse nie, maar onregstreekse kommunikasie plaas.

Wilson gebruik Christus se onderwysmetode om dit te verduidelik. Wanneer aan Hom 'n vraag gestel is, het Hy gewoonlik nie geantwoord deur vanaf 'n beginpunt na 'n konklusie te redeneer nie. Hy het gewoonlik sy "punt" gemaak deur 'n verhaal of gelykenis te vertel, sonder om die waarheid eksplisiet te stel. Op indirekte, subtiele, verbeeldingryke wyse gestel, moes die hoorder self die antwoord/konklusie ontdek.

Wilson (1997: 149, 150) som op: "The truth thus comes across in an allusive rather than a direct way; it is implicit rather than explicit. By means of this creative approach, the listener usually ends up 
convincing himself. This technique was effective, for it veiled the truth from frontal view". Hierdie manier van omgang met die medemens is ook tipies van Afrika (vgl. 1.2). Dit kom ook voor by 'n ander Oosterse volk, die Japanners.

\section{3 'n Vergelyking tussen die Westerse en moderne Japannese denke, volgens Hall en Hall (1987)}

Die meeste van die eienskappe wat Boman en Wilson by die oudOosterse denke aangetoon het, word teruggevind in die hedendaagse denkwyse van Japan. Hall en Hall (1987) se boek stel ons ook in staat om in nog meer besonderhede die kontoere van die Oosterse "gees" bloot te lê.

\subsubsection{Kommunalisme}

Die kommunalistiese trek van die Japannese denke word nie alleen deur Hall en Hall sterk beklemtoon nie, maar hulle spel die implikasies daarvan ook in besonderhede uit. Hulle omskryf die Japannese kommunalistiese ingesteldheid soos volg: "The crucial point is that one's personal identity is rooted in the soil of one's dependent and interrelated relations to others as a member of the group. In contrast, the American and European seeks his identity not as a cog in a larger machine but as an individual" (Hall \& Hall, 1987: 55-56).

Myns insiens is die Halls se vergelyking van die kommunalisme met 'n rat in 'n masjien, nie gepas nie. Dit is 'n Westerse, meganistiese beeld - die gemeenskapsgevoel is baie hegter en kan eerder met 'n organiese beeld, soos dié van 'n liggaam en sy ledemate vergelyk word.

Die implikasies van die feit dat 'n hegte gemeenskapsgevoel vir die Japanners "die sleutel tot alle menseverhoudinge" is, is die volgende:

- Vir die Japannese "people-centered"-kultuur is sake/produkte/ dinge nie die belangrikste nie - vir die Weste wel. Menseverhoudings is in Japan die primêre fokus (vgl. Hall \& Hall, 1987:72).

- Nie privaatheid (die Weste) nie, maar groepsidentiteit is belangrik (vgl. Hall \& Hall, 1987:56).

- In plaas van individuele regte (die Weste), word verantwoordelikheid en lojaliteit teenoor die groep hoog aangeslaan. 
- Nie individuele prestasie nie, maar die gesamentlike prestasie van die groep word waardeer. Kompetisie (die Weste) is nie belangrik nie, maar spanwerk wel (vgl. Hall \& Hall, 1987: 67).

- In Japan is mondelinge beloftes en ooreenkomste veel eerder bindend as onderhandelde, skriftelike, wetlike kontrakte (die Weste) (vgl. Hall \& Hall, 1987:66, 129).

- Besluite word nie (soos meestal in die Weste) deur 'n meerderheidstem geneem nie, maar daar word gepraat totdat konsensus bereik is (vgl. Hall \& Hall, 1987:12, 82).

- 'n Goeie leier word nie gesien (soos die geval in die Weste is) as 'n sterk individu wat op outokratiese wyse sy stempel op sy volgelinge kan plaas nie. ' $n$ Leier is volgens Japanners eerder iemand wat die vermoë het om noukeurig en geduldig na ander te luister en dan te sorg dat die groep eenstemmigheid bereik en harmonies saamwerk (vgl. Hall \& Hall, 1987:78, 79).

- Omdat Japanners nie prosedure-georiënteerd is soos die Westerlinge nie, maar mensgeoriënteerd, word agendas en skedules ook anders beskou. Die Japanners redeneer dat almal reeds in hoofsaak weet waaroor ' $n$ vergadering gaan. Daar hoef dus nie streng by agendapunte en vergaderingprosedure gehou te word nie. Dit is ook nie verspilling van tyd om elkeen die geleentheid te gee om sy sê te sê nie, want op dié wyse word uiteindelik harmonie en konsensus bereik (vgl. Hall \& Hall, 1987:81). Japanners hou verder nie daarvan dat feite vooraf (byvoorbeeld deur Westerse buitestaanders) vir hulle geselekteer word nie (vgl. Hall \& Hall, 1987:120).

- Persoonlike ruimte (die fisiese spasie tussen persone tydens 'n gesprek) word deur veral die noordelike Westerlinge groot gehou, anders ervaar hulle die ander persoon as opdringerig. In Japan is die kommunikasie-afstand egter baie kleiner - om 'n groot ruimte te handhaaf, sou op koudheid en afsydigheid dui (vgl. Hall \& Hall, 1987:13).

- Senioriteit is in Japan belangriker as jeugdigheid. Mense word dus meestal op grond van senioritiet en nie op grond van hul prestasie (soos in die Weste) bevorder nie.

- Spesifieke soort deugde wat goeie menseverhoudinge bevorder (bv. tegemoetkomendheid en plooibaarheid), word in Japan hoog waardeer, terwyl die moderne Weste 'n hoër premie plaas op 
deugde soos selfgelding, kompeterendheid en selfs aggressiwiteit (vgl. Hall \& Hall, 1987:70).

Die teenpool van hierdie Japannese oriëntasie op die eie (in)groep, is egter die feit dat hulle mense uit 'n buitegroep as "non-persons" beskou en ook sodanig behandel (vgl. Hall \& Hall, 1987:60).

\subsubsection{Indirekte kommunikasie}

Indirekte kommunikasie hang saam met die hoë premie wat op menseverhoudings in Japan geplaas word. Omdat dit so belangrik is, word egter afsonderlik meer daaroor gesê. (Vergelyk ook punt 1.2 en 2.2.5) Hoe belangriker en sensitiewer die gesprek, hoe meer indirek sal dit geskied.

Aangaande die verskil tussen die Amerikaners (dit geld ook vir ander Europese volke) en die Japanners stel Hall en Hall (1987:122, 123) dit breedvoerig:

Americans communicate directly and look at the other person when they speak. They come right to the point and ask direct questions. These highly valued communication styles are unnerving to the Japanese, whose whole manner is marked by indirection. They are made uncomfortable by Americans who look at them directly; they choose to look down or at the corner of the room. Japanese try to gather information without asking direct questions, and they talk around the subject. For Japanese, frankness and bluntness are taboo; even exactness is to be avoided because it is considered arrogant and impertinent.

Tereg vervolg hulle verder:

This manner creates difficulties for the more impatient Americans, as it takes time to discover things simply by watching and listening. The American in Japan is likely to ask himself, "Why beat around the bush? Why not come straight out and say what's on your mind? They are going to find out anyway, so why waste time?' The point is, by saving time in the short term, less information is shared, the relationship suffers, and long-term goals are threatened (Hall \& Hall, 1987:122).

Die Halls voeg nog daaraan toe dat Westerlinge in so 'n gesprek nie maklik daarin sal slaag om die Japanners te mislei nie. Hulle het byna 'n X-straal vermoë om deur enige fasade te sien. Verder moet ook nie sommer aanvaar word dat wanneer 'n Japanner "ja" sê, hy werklik "ja" bedoel nie. Daarmee kan hy slegs bedoel "ek hoor wat jy sê". 'n Glimlag hoef ook nie instemming te beteken nie, maar kan 
eerder 'n teken van verleentheid wees (vgl. Hall \& Hall, 1987:124). Kultuur beïnvloed duidelik ook liggaamstaal.

Behalwe die kommunalistiese groepsingesteldheid, is die diepste agtergrond hiervan dat die Japannese kultuur 'n skaamtegeoriënteerde kultuur is (vgl. Van der Walt, 2004b en veral Wiher, 2003 vir die onderskeid tussen 'n skaamte- en 'n skuldgewete). Dit is vir hulle belangrik dat niemand in verleentheid kom en tot skande gemaak word nie of "gesig verloor" nie.

Praktiese wenke om met mense uit die Ooste (en Afrika) te kommunikeer, is dus:

Luister aandagtig; wees baie geduldig; beklemtoon ooreenstemming; moenie 'n voorstel direk van die hand wys nie, maar sê eerder jy sal daaroor nadink; wees hoflik en moet nooit konfronterend wees, jou vinger na iemand wys of hom kwaai in die oë kyk nie; probeer eerder oorreding as druk toepas; moenie net aanhoudend praat nie, maar gee tyd vir nadenke; wees fyn ingesteld op die emosionele sy van die gesprek, omdat mense van hierdie kulture ingesteld is op die "silent language" van nie-verbale liggaamstaal; gee die globale prentjie, in plaas daarvan om in detail te verval; vermy die Westerse strak, rigiede logika - dit beïndruk nie mense van hierdie kulture nie.

\subsubsection{Denke oor tyd}

Moontlik lê Hall te veel klem op die rol van die tydsvisie van 'n bepaalde kultuur (Hall, 1981). Nogtans speel tydsvisie 'n belangrike rol in die manier waarop mense dink. Hall en Hall (1987:16-19) onderskei tussen die monokroniese tyd van die Weste en die polikroniese tyd van Japan. Die belangrikste verskil tussen dié twee visies is dat in eersgenoemde 'n mens verkieslik net een ding op ' $n$ slag doen, terwyl in laasgenoemde ' $n$ mens by baie dinge en mense gelyktydig betrokke kan wees.

Hall en Hall (1987:17) verduidelik dit soos volg:

In monochronic cultures, time is experienced and used in a linear way - comparable to a road extending from the past into the future. M-time is divided ... into segments; it is scheduled and compartimentalized, making it possible for a person to concentrate on one thing at a time. In a mono-chronic system the schedule may take a priority above all else and has to be treated as sacred and unalterable ... People talk about time as though it was money, as something that can be 'spent', 'saved', 'wasted' and 'lost'. It is 
also used as a classification system for ordering life and setting priorities: 'I don't have time to see him' (Hall \& Hall, 1987:17).

In feitlik elke opsig is polikroniese tydsisteme die antitese van die Westerse visie op tyd en die gebruik daarvan. "P-time is characterized by the simultaneous occurrence of many things and by a great involvement of people. There is also more emphasis on completing human transactions than on holding to schedules" (Hall \& Hall, 1987:17).

Hall en Hall noem die voorbeeld van twee persone wat mekaar toevallig ontmoet, begin gesels en liewer laat vir 'n belangrike afspraak sal wees as om hulle gesprek kort te knip. Mense wat in Pstyl dink, konsentreer dus nie op hulle werk nie, maar op mense en laat gevolglik hulle aandag maklik aftrek. Ook planne en afsprake word makliker en meer dikwels verander as in die Westerse denkstelsel (Hall \& Hall, 1987:18). As gevolg van verwestering respekteer die hedendaagse Japanner albei tydsisteme: In hulle verhouding met Westerlinge volg hulle M-tyd, maar in die interpersoonlike verhoudings met hul eie groep, is P-tyd nog steeds die norm.

\subsubsection{Logika}

Hall en Hall $(1987: 97,120)$ beklemtoon dat Japanners negatief reageer op die Westerse "liniêre" logika. Vir Japanners is dit 'n belediging as iemand anders uit die Weste die feite vir hulle volgens 'n vreemde logika wil orden. Dit kom daarop neer dat jy namens die Japanners wil dink. (Byna so opdringerig as wanneer iemand ongevraagd jou huismeubels vir jou (her)rangskik). Volgens hierdie Oosterse volk is die liniêre, stap-vir-stap, analitiese logika selfs 'n teken van onvolwasse denke. Die Japanners is dus nie oppervlakkig in hul denke nie, maar redeneer op hulle eie, unieke manier.

Ongelukkig tipeer Hall en Hall (1987:121) nie hierdie interresante manier van dink nie, maar gee slegs 'n voorbeeld. Daaruit blyk dat dié Japannese denkwyse soortgelyk is as die blok-logika van die Hebreërs soos deur Wilson beskryf. Dit is 'n meer holistiese as analitiese denkwyse, wat alle moontlike fasette en onderlinge verhoudings en invloed op mekaar in oënskou neem. 


\subsection{Samevattende vergelyking tussen die Westerse en Oosterse denkwyse}

Die belangrikste verskille wat uit die voorafgaande besprekings blyk, is met trefwoorde oorsigtelik in Tabel 1 saamgevat.

\section{Tabel 1}

\begin{tabular}{|c|c|}
\hline DIE WESTE & DIE OOSTE \\
\hline $\begin{array}{l}\text { 1. Fokus op die (kennis van) die synde } \\
- \text { staties }\end{array}$ & $\begin{array}{l}\text { Fokus op die (kennis van) gebeure - } \\
\text { dinamies }\end{array}$ \\
\hline $\begin{array}{l}\text { 2. Die individu die belangrikste - } \\
\text { individualisties }\end{array}$ & $\begin{array}{l}\text { Die gemeenskap die primêre - } \\
\text { kommunalisties }\end{array}$ \\
\hline $\begin{array}{l}\text { 3. Monokroniese tydskonsepsie en } \\
\text {-gebruik }\end{array}$ & $\begin{array}{l}\text { Polikroniese tydskonsepsie } \\
\text {-gebruik }\end{array}$ \\
\hline $\begin{array}{l}\text { 4. Skeiding tussen die profane en } \\
\text { sakrale - dualistiese denke }\end{array}$ & $\begin{array}{l}\text { Die hele lewe is religie - integrale } \\
\text { denke }\end{array}$ \\
\hline 5. Ingestel op gehoor - ouditief & Ingestel op sien - visuele denke \\
\hline $\begin{array}{l}\text { 6. Konseptuele denke - begrippe is } \\
\text { belangrik }\end{array}$ & $\begin{array}{l}\text { Relasionele denke - verhoudinge is } \\
\text { belangrik }\end{array}$ \\
\hline 7. Logiese denke & Psigiese (emosionele) denke \\
\hline 8. Objektief-saaklik & Subjektief-persoonlik \\
\hline $\begin{array}{l}\text { 9. Abstrak }- \text { verwyder van die } \\
\text { voorwerp vir kennis }\end{array}$ & $\begin{array}{l}\text { Konkreet - nader aan die objek van } \\
\text { kennis }\end{array}$ \\
\hline 10. Analities - gerig op onderdele & $\begin{array}{l}\text { Holisties (sinteties) - fokus op die } \\
\text { geheel }\end{array}$ \\
\hline $\begin{array}{l}\text { 11. "Argitektonies" - 'n gedagte bou op } \\
\text { 'n voorafgaande }\end{array}$ & $\begin{array}{l}\text { "Musikaal" - die sentrale tema of punt } \\
\text { word herhaal }\end{array}$ \\
\hline 12. Stap-logika & Blok-logika \\
\hline $\begin{array}{l}\text { 13. Waarheid is primêr vir die regte } \\
\text { denke }\end{array}$ & $\begin{array}{l}\text { Waarheid is nodig vir die regte } \\
\text { handelinge }\end{array}$ \\
\hline $\begin{array}{l}\text { 14. Direkte kommunikasie van die } \\
\text { waarheid }\end{array}$ & $\begin{array}{l}\text { Indirekte kommunikasie van die } \\
\text { waarheid }\end{array}$ \\
\hline
\end{tabular}

\subsection{Voorlopige gevolgtrekking}

Veral die gevolgtrekking dat kennis nie net deur logiese denke (dié tendens by die Weste) verkry kan word nie, is belangrik. Die 
Oosterse kultuur herinner Westerlinge daaraan dat 'n mens veel meer kan weet (kennis kan verwerf) as wat 'n mens intellektueelanalities kan (be)dink.

Die oud-Oosterse kultuur - wat ook in die Ou en Nuwe Testament neerslag gevind het - het groot klem op wysheid gelê. Wysheid beteken om, langs verskillende weë, die regte insig/kennis te bekom en dan in ooreenstemming daarmee te handel. Wysheid is dalk skaars in die moderne Westerse wêreld juis omdat kennis eensydig met intellektuele vermoë en redelike insig verwar en daartoe vereng word.

Goldsworth (1995:157) sê oor die Israelitiese wysheid:

The prerequisite for wisdom is not a high I.Q. but the fear of the Lord ... rather than intellectual wizardry ... a new view of reality which Paul speaks of as the renewing of our minds (Romans 12:2) ... thus, from the biblical point of view, the youngster who is intellectually 'slow' but who has a simple trust in Jesus as Saviour, is wiser than the brilliant philosopher who, despite his intellectual powers, refuses the knowledge of God in his Word.

Hierdie vernuwing van ons gemoed (OAV) of denke (NAV) sluit veel meer in as ' $n$ blote logiese, analitiese aktiwiteit. Die ontmoeting met die Oosterse denke kan moontlik 'n belangrike bydrae lewer om dit te begryp.

Vervolgens kan die vraag gestel word of die denkwyse van Afrika die Westerse denke kan verryk.

\section{3. 'n Vergelyking tussen die denkwyse van die Weste en (tradisionele) Afrika}

In hierdie afdeling word ter inleiding enkele struikelblokke uit die weg geruim. Daarna volg 'n skematiese vergelyking van die Westerse en Afrikadenke, die lewensbeskoulike agtergrond van dié denkwyse word kortliks geskets en ten slotte word die aandag gevestig op die groot ooreenkomste tussen die Afrika- en Oosterse denke.

\subsection{Struikelblokke}

Dit is nie maklik om die kontoere van die Afrikamanier van dink vas te stel nie. Daar bestaan belangrike onderlinge kultuurverskille tussen die verskillende etniese groepe en streke in Afrika, wat nie oor die hoof gesien mag word nie. Tog kan die algemene trekke van die Afrikadenke geïdentifiseer word (vgl. byvoorbeeld die skema- 
tiese vergelykings tussen Afrikadenke en die Westerse denkwyse in O'Donovan, 2000:21 en Wiher, 2003:428-431).

Veral in die stedelike gebiede het grootskaalse verwestering reeds plaasgevind, sodat die oorspronklike, tradisionele Afrikadenkwyse nie meer oral suiwer aangetref word nie. Verskillende skrywers vestig egter die aandag daarop dat die tradisionele denke, ten spyte van baie invloede van buite, taai oorlewingskrag vertoon.

Daar bestaan wel baie antropologiese stof oor verskillende Afrikakulture, maar min spesifiek oor die Afrikadenkwyse. Enkeles is byvoorbeeld Bujo (1998), Du Preez (1976; 1978), Gyekye (1995; 1997), Hallen (1996), Horton (1993; 1996), Nyasani (1988; 1997), Nkemnkia (1999) en Sogolo (1993). Selfs bronne oor tradisionele Afrikafilosofie bied min inligting oor die Afrikane se denkwyse.

O'Donovan (2000:21), Wiher (2003:428-431) en Van der Walt (2004a:187-188) bied egter nuttige geheeloorsigte oor die Afrikadenkwyse. Kennis van die Westerse denkwyse word ook hier weer veronderstel. Vir meer besonderhede daaroor, vergelyk byvoorbeeld Tarnas (1991).

\subsection{Oorsig}

Die belangrikste verskille word met trefwoorde oorsigtelik in Tabel 2 saamgevat:

\section{Tabel 2}

\section{DIE WESTE}

\section{AFRIKA}

A. Die doel/gerigtheid van kennis

1. Wetenskaplik-tegniese beheersing van die sigbare werklikheid

Magies-rituele manipulasie van die geesteswêreld

2. Gefokus op kennis van universele wetmatighede

Gefokus op individuele, konkrete verskynsels

3. Konseptuele gerigtheid - begrippe is belangrik

Relasionele gerigtheid - verhoudings is belangrik

4. Kennis ter wille van beter insig in dinge - epistemologie belangrik

Kennis ter wille van die regte handelinge - etiek is belangrik 


\section{B. Die aard van die kenner}

5. Klem op die enkeling - individuele outonomie

6. Kontekstueel onafhanklik

7. Meer progressief - oop vir nuwe idees

8. Selfstandig-kritiese instelling
Klem op die mens in gemeenskap sosiaal sensitief

Kontekstueel gebonde

Meer tradisiegebonde - aanvaar moeiliker nuwe idees

Geneig tot blote reproduksie van feite

\section{Die kenaktiwiteit of -proses}

9. Gehoor is belangrik - ouditiewe Sien is belangrik - visuele manier manier

10. Meer rasioneel

Meer intuïtief

11. Meer intellektueel en saaklik

Meer gevoelvol

12. Dualisties - geloof en ander voorveronderstellings mag nie 'n rol Integraal - voorveronderstellings word speel in die kenproses

betrek by die kenproses

\section{Die aard van die kenobjek}

13. Die materiële dinge
$\begin{aligned} & \text { 14. Afstand tussen kenner en ken- } \\ & \text { voorwerp }\end{aligned}$

15. Die natuurlike oorsake en wette wat dinge reguleer

16. Die kenobjek word meer staties beskou

Die geestelike magte en kragte

Kenner nouer betrokke by die kenobjek

Die geestelike (bonatuurlike) oorsake wat die gebeure bepaal

Die kenobjek word as dinamies gesien

\section{E. Die kenmerke van die kenresultaat (kennis)}

\begin{tabular}{|c|l|}
\hline $\begin{array}{c}\text { 17. Abstrakte kennis, gedistansieer } \\
\text { van werklikheid }\end{array}$ & $\begin{array}{l}\text { Konkrete kennis, nader aan die } \\
\text { kenobjek }\end{array}$ \\
\hline $\begin{array}{c}\text { 18. Analities-gereduseerde kennis van } \\
\text { onderdele }\end{array}$ & $\begin{array}{l}\text { Sinteties-integrale kennis waarin die } \\
\text { hele objek en sy verhoudinge betrek } \\
\text { is }\end{array}$ \\
\hline $\begin{array}{c}\text { 19. Sistematies - volgens 'n duidelike } \\
\text { kategoriale raamwerk georganiseer } \\
\text { om 'n patroon/sisteem te vorm }\end{array}$ & $\begin{array}{l}\text { Op die oog af onsistematies - detail is } \\
\text { nie sistematies volgens 'n logiese } \\
\text { raamwerk verbind nie }\end{array}$ \\
\hline
\end{tabular}


20.Stap-logika: een gedagte word logies op 'n voorafgaande gebou met 'n duidelike gevolgtrekking; meer rigied - oordele is óf reg óf verkeerd; meer op verskille as ooreenkomste gerig
Blok-logika: die sentrale tema word dikwels herhaal sonder 'n duidelike konklusie; meer vloeibaar en aaneenlopend (én-én styl); meer op analoë en ooreenkomste gerig as op verskille

\section{F. Hoe kennis (waarheid) oorgedra word}

21. Die waarheid word sonder om Die waarheid word baie omsigtig, op doekies om te draai reguit 'n indirekte manier oorgedra meegedeel

Die verskille tussen die Westerlinge en Afrikane is nie oral ewe duidelik nie. Daarom word die woorde "meer"/"minder" soms by die vergelyking gebruik. Daar is gepoog om op vorige weergawes uit te brei en te verbeter, deur nie net te konsentreer op hoe mense dink nie (die kognitiewe kenaktiwiteit), maar deur die hele kenproses te betrek: Die kenner (B) rig sy kenaktiwiteit (C) op die kenbare objek (D) om 'n kenresultaat (E) te bereik. Vooraf is dit egter ook belangrik om te weet wat die doel (A) van kennis is en ten slotte hoe die kennis (waarheid) meegedeel word (F). Hiermee word 'n veel breër beeld van die kenwyses van die Weste en Afrika gegee as wat die bestaande literatuur bied.

'n Verdere verduideliking van die verskillende eienskappe (1-21) is vir die doel van hierdie oorsigtelike ondersoek nie nodig nie (vgl. Van der Walt, 2004a:189-196). Kennis van die breëre lewensbeskoulike agtergrond waarin dié tipiese Afrikamanier van dink gewortel is, is belangrik.

\subsection{Die diepere, lewensbeskoulike agtergrond}

Die Afrika-kenproses en die groot verskille met dié van die Weste kan alleen goed verstaan word teen die agtergrond van die tradisionele Afrikalewensvisie. In dié opsig is Steyne (1989:176-185; 240-242) se beskrywing van die animisme waardevol.

In die animistiese werklikheidsvisie van tradisionele Afrika word min of geen onderskeid tussen die materiële en geestelike wêrelde gemaak. Hulle is één - alles is gees(telik). Indien hulle (op Westerse wyse) onderskei sou word, is die geesteswêreld egter die bepalende. Hierdie geesteswêreld is egter onvoorspelbaar en daarom leef die Afrikaan in voortdurende vrees dat hy deur die voorouergeeste, ander geeste en gode benadeel kan word. Dit is dus van die allergrootste belang om die geesteswêreld, die oorsaak 
van sowel goed as kwaad, te ken. Dié kennis stel iemand in staat om met allerlei soorte rituele die onvoorspelbare, magiese geesteswêreld in sy guns te manipuleer. Krag om in die samespel van geestelike kragte te oorleef, is belangriker as kognitiewe refleksie. Kennis word dus nie ter wille van kennis nagestreef nie, maar om te midde van die onvoorspelbare geesteskragte reg te kan optree.

Terwyl die Westerse, wetenskaplike denke ten doel het om die wetmatighede van veral die fisiese werklikheid op te spoor - vrae soos wat? en hoe? is belangrik - is die Afrikaan byvoorbeeld nie tevrede met wat presies by 'n moord gebeur het en hoe dit plaasgevind het nie. Hy wil eerder weet wie die moordenaar daartoe aangespoor het en waarom dit gedoen is. Om dieselfde rede is die wetenskaplike feit dat malaria deur 'n sekere muskiet veroorsaak word vir die tradisionele Afrikaan nie voldoende nie. Volgens sy animisties-magiese lewensvisie wil hy weet wie die muskiet na hom toe gestuur het en waarom (die gees/persoon) dit gedoen het.

Die holistiese Afrikalewensvisie (dat alles één is), verklaar ook die feit waarom Afrikane nie analities nie (op onderdele gerig), maar eerder sinteties dink.

Dit is ook duidelik dat in 'n lewensvisie waarin die balans tussen geesteskragte so ' $n$ belangrike rol speel, magiese denke belangriker is as rasionele denke.

Die sterk kommunalistiese ingesteldheid by die mense van Afrika verklaar verder waarom hulle denke so sterk kontekstueel- en tradisiegebonde is. Onafhanklike, kritiese denke is nie die norm nie, maar moet eerder as eksentriek beskou word - dit druis in teen die gevestigde gemeenskaplike kennis.

Die feit dat in Afrika nie 'n duidelike ontologiese onderskeid gemaak word tussen gode, geeste, mense, diere, plante en stoflike dinge nie (synsrelativisme), word ook weerspieël in die Afrikadenkwyse waarin 'n duidelike kategoriale raamwerk ontbreek. Afrikane se "logika" is nie rigied nie, maar vloeibaar en verskillende dinge en gebeure, wat vir die Westerling geen verband het nie, word aaneengeskakel.

Die bedoeling van hierdie artikel is nie om volledig die lewensvisie van tradisionele Afrika te verduidelik nie. Met hierdie enkele voorbeelde word egter beklemtoon dat Afrikane se denkwyse nie werklik grondig verstaan kan word sonder om dit teen die agtergrond van hulle meer omvattende lewensbeskouing te plaas nie. (Vir meer besonderhede daaroor vergelyk Van der Walt, 2004a: 
61-92, 133-175). Daar is juis in hierdie opsig 'n leemte by die meeste studies van kognitiewe psigoloë oor hierdie soort denkwyse.

\subsection{Die ooreenkoms van die Afrikadenkwyse met dié van die Ooste}

Slegs 'n vlugtige vergelyking tussen Tabel 1 (2.4) en Tabel 2 (3.2) toon duidelik aan hoe groot die ooreenkoms is tussen die tradisionele Afrikadenke en die antieke, sowel as moderne, Oosterse denkwyse. In hulle onderlinge ooreenkoms kontrasteer hulle ook skerp met die Westerse denke.

Bogenoemde feit verg ernstige nadenke. Op kulturele gebied oefen die Westerse kultuur wêreldwyd steeds meer invloed uit, byvoorbeeld op die gebied van die ekonomie, tegnologie, media en onderwys. Op hierdie en nog baie ander terreine word die Westerse kultuur, lewensvisie en denkwyse nie net uitgedra nie, maar dikwels op die nie-Westerse wêreld afgedwing.

Getallegewys maak die Ooste en Afrika egter die grootste deel van die wêreldbevolking uit. Ongeag die getalle-oorwig, behoort elke kultuurgroep egter die reg te hê om sy eie kultuur te beskerm. Is dit dan reg en gesond dat die Westerse kultuur en denkwyse - wat uit die voorafgaande uiteensetting duidelik geblyk het eensydig te wees - as die universele, globale norm aanvaar word? Kan dit nie 'n wêreldwye verarming tot gevolg hê nie?

Omdat so 'n dringende vraag nie in die bestek van 'n artikel behandel kan word nie, word ten slotte slegs die onderwyssituasie in Afrika as voorbeeld behandel.

\section{Die Afrikanisering van die onderwys}

Hierdie slotgedeelte word beperk tot twee studies uit Afrika, waarvan die eerste die Afrikanisering van onderrig- en leerstyle beklemtoon, terwyl die tweede ondersoek aandag daarvoor vra dat die meer Westerse selfstandige analitiese denke nie in die onderwys mag ontbreek nie.

\subsection{Afrikanisering van leer- en onderwysstyle}

Terwyl Earl Bowen (1984) meer op die leerstyle van Afrikastudente toegespits het, het Dorothy Bowen (1984) op die beste onderrigstyle gefokus. Saam publiseer hulle, in gepopulariseerde vorm, die resultate van hulle ondersoek in Bowen en Bowen (1984 en 1986). In haar studie word die noodsaak van die Afrikanisering van die 
onderwys sterk deur Dorothy beklemtoon. Dit word verder hier behandel.

\subsubsection{Westerse onderwys}

Hoewel dit goed bedoel was, het die Westerse manier van onderwys, gedurende die koloniale periode maar ook daarna, nie rekening gehou met die tradisionele kultuur en denkwyse van die mense van Afrika nie. Dit het selfs daarmee gebots (vgl. Bowen, 1984:2-7). Afrikane het hierdie soort onderwys beskou as té abstrakakademies, té veel gefokus op memorisering en té eksamengerig. Hulle kon as gevolg van vreemde onderwysmetodes ook nie op hulle beste presteer nie. Bowen se ondersoek wil dus vasstel wat die kognitiewe style van die Afrikastudente is en dan onderwysstyle probeer vind wat daarby aanpas.

\subsubsection{Kognitiewe style en metodes om dit te bepaal}

Kognitiewe style dui op die manier waarop 'n mens van jou omgewing kennis neem, inligting verkry en daaruit betekenis skep (vgl. Bowen, 1984:20). Baie faktore speel 'n rol in die wyse waarop dit gebeur, soos byvoorbeeld die eie kultuur, agtergrond, ervaringswêreld en familie.

Kennis van kognitiewe style is veral in die onderwys belangrik, want dit bepaal die volgende: leerlinge en studente se belangstellings, voorkeure vir sekere soorte leerstof en selfs beroepskeuses; leerders se akademiese ontwikkeling; hoe studente (die beste) leer en hoe onderwysers/dosente klasgee. Daar bestaan verskillende psigologiese toetse om leerstyle vas te stel.

Bowen gebruik in twee toetse die "field-dependent" en "fieldindependent" benadering. Die keuse val op dié metode, omdat dit volgens haar van al die metodes die meeste toegepas is - ook op die onderwys (Bowen, 1984: 23-26).

Die onderskeid tussen "field-dependent" (fd) en field-independent" (fi) handel veral oor die manier waarop die persoon (kenner) die veld, terrein of objek van kennis ervaar. 'n Persoon dink fd (meer holisties) as die onderdele van die veld saamsmelt, terwyl iemand fi dink as hy/sy duidelik die onderdele onderskei (dus meer analities dink).

'n Fd-persoon is meer afhanklik van sy omgewing en eksterne sosiale verhoudinge, terwyl 'n fi-mens meer individualistiesoutonoom dink. Eersgenoemde is dus meer mensgeoriënteerd, 
terwyl laasgenoemde meer saaklik en taakgeoriënteerd is. Dit is dus duidelik waarom fd-leerlinge/-studente in die leerproses sterk van die strukturering en leiding van hulle leermeesters afhanklik is, terwyl fi-persone meer selfstandig kan en wil leer.

Dit is verder belangrik om die aandag daarop te vestig (vgl. Bowen, $1984: 19,29,121)$ dat kognitiewe style nie meet hoe intelligent leerlinge is nie, maar die manier waarop hulle dink. Verder beteken aanpassing van die onderwys by die leerstyle van die studente ook nie dat die inhoud van die onderwys hoef te verander nie, maar slegs die metodes.

\subsubsection{Resultate}

Bowen (1984:123) bevind dat 91\% van al die getoetste Afrikastudente $\mathrm{fd}$ is. Dit is die hoogste by teologiese studente (97\%), terwyl dit by regeringskole heelwat laer is (83\%). Verder is daar ook streeksverskille. Wes-Afrikaanse (Nigeriese) studente is $100 \% \mathrm{fd}$, terwyl Oos-Afrikaanse (Keniaanse) studente slegs $84 \% \mathrm{fd}$ is.

Hierdie psigologiese toetse bevestig dus my eie kultuur-filosofiese oorsig van die Afrikadenkwyse (vgl. numering in Tabel 2). Fd dui onder andere op die volgende maniere van dink: relasioneel (3), gemeenskapsgeoriënteerd (5), tradisiegebonde (7), reproduktief (8), visueel (9), noue betrokkenheid by die kenobjek (14), konkreet (17) en sinteties-integraal (18).

\subsubsection{Aanbevelings}

Bowen $(1984: 109,120)$ kan dus nie sonder meer aanvaar dat Afrikastudente op dieselfde wyse as Westerse studente dink en leer nie. In die plek daarvan (Bowen 1984:111-117) beveel sy 26 nuwe onderwysstrategieë aan wat beter aansluit by die dink- en leerwyse van Afrikane. Beperkte ruimte laat alleen drie voorbeelde toe.

- Omdat Afrikastudente meer integraal-holisties dink, is geheeloorsigte van die werk en die leerstof vir hulle waardevol.

- In aansluiting by die sterk gemeenskapsgevoel (kommunalisme), beveel Bowen aan dat individuele kompetisie tussen studente nie 'n goeie onderwysmetode is nie. Prestasie moet nie aan ander studente gemeet word nie, maar aan onpersoonlike kriteria. Verder moet studente soveel moontlik toegelaat word om in groepe te studeer (bv. groepsbesprekings, groepsopdragte en selfs groepsreferate). 
- Omdat Afrikastudente sterk visueel ingestel is, is die tradisionele lesingmetode (net luister) nie ideaal nie. Verskillende soorte leeswerk, die gebruik van 'n oorhoofse projektor, films, videos, skyfies, illustrasies, rolspel, veldwerk en ander konkrete ervarings is veel gepaster en meer effektief.

\subsection{Stimulering van selfstandige analitiese denke}

Buconyori (1991) gebruik vir sy ondersoek ook die fd-fi-metode en sy resultate stem ooreen met dié van Bowen. Sy bevinding is dat $79.24 \%$ van die getoetste studente fd en slegs $20.58 \%$ fi dink. Weereens is teologiese studente meer fd (90\%) as die studente van Christelike "liberal arts" kolleges wat net $77.58 \% \mathrm{fd}$ is. (Wat sou die rede wees? Lê dit dalk by die soort onderwys - die feit dat die meeste teologiese skole nie selfstandige denke stimuleer nie?) Verder is dit interessant dat damestudente meer fd is as mans. Buconyori se psigologiese toetse bied terselfdertyd ook ' $\mathrm{n}$ bevestiging van my samevattende oorsig in Tabel 2.

\subsubsection{Meer krities}

Hoewel Buconyori in baie opsigte bou op die werk van Bowen, is hy meer krities ingestel. Hy probeer byvoorbeeld om sy toetse beter aan te pas by Afrikastudente. Hy voer aan (Buconyori, 1991:46) dat die standaard psigometriese toetse om kognitiewe style te bepaal sterk kultuurgebonde (Westers) is; as gevolg daarvan word fidenkende studente bevoordeel; die toetse gaan van die veronderstelling uit dat mense óf fd óf fi dink en kan dus nie studente toets wat in albei ewe sterk is nie; die toetse is te eng ruimtelik-fisies georiënteerd.

\subsection{2 'n Eie bydrae}

Hoewel Buconyori waardering het vir die feit dat Bowen en andere onderwysstyle aanbeveel wat beter by die leerstyle van die Afrikastudente aanpas, beskou hy dit nie as genoegsaam om die onderwyssituasie in Afrika te verbeter nie. Volgens hom (Buconyori, 1991:179) het sy voorgangers nie aangetoon wat gedoen kan word om die redeneervermoë van Afrikastudente te verbeter nie. Daarmee bedoel hy nie dat Afrikane nie kan redeneer nie, maar wel dat hulle nie (soos Westerlinge) sterk is in selfstandige analitiese denke nie. Hulle is geneig om byna meganies die voorgeskrewe stof te memoriseer en net so weer in toetse weer te gee (Buconyori, 1991:5). Hulle ondervind moeite met analise, bevraagtekening en 
kritiese evaluering om logiese gevolgtrekkings te bereik (Buconyori, 1991:106).

Hierdie stand van sake is nie in ooreenstemming met die hoofdoel van hoër onderwys en studie nie, naamlik om leerders in denkers te omskep (vgl. Buconyori, 1991:50). Buconyori formuleer daarom die doel van sy studie soos volg:

The purpose of this research was to explore the various ways African students use their minds to think and reason. The ultimate goal was to determine possible implications for better teaching and encouraging reasoning in higher education in general and Christian higher education in particular in East Africa (Buconyori, 1991:172, vergelyk ook p. 94).

Hierdie navorser besef dat moderne onderwys by die tradisionele kultuur moet aansluit, maar ook dat die meer Westerse selfstandige analitiese denkwyse gestimuleer moet word.

\subsubsection{Praktiese wenke}

Die vraag is dus hoe onderwysstrategieë ontwerp kan word wat by die kognitiewe style van die Afrikane aansluit en tog selfstandige redeneervermoëns bevorder. Vir Buconyori (1991:173) is selfstandige analitiese denke die vermoë om tussen baie feite die belangrikste te kan selekteer, dit by bestaande kennis te integreer, afleidings daaruit te kan maak om tot logiese gevolgtrekkings te kan kom.

Van die strategieë wat Buconyori (1991:185 e.v.) aan die hand doen om só 'n tipe denkwyse te bevorder, word slegs 'n paar voorbeelde genoem:

- Sluit aan by die visuele ingesteldheid van die studente, sonder om daarby te bly staan.

- Die feitlike kennis (inhoud van leerstof) moet op so 'n wyse aangebied word dat dit nadenke bevorder. Die dosent moet dus doelbewus baie vrae stel en ook sy studente stimuleer om hulle eie vrae te formuleer.

- Help die student om op die belangrikste aspekte van die onderwerp te fokus en die werklike probleme te identifiseer.

- Stimuleer kreatiwiteit deur nuwe idees te skep. Doen dit, in aansluiting by die kommunalistiese oriëntasie van die studente, koöperatief in groepe en nie in die vorm van kompetisie tussen idividue nie. 
- Analitiese denke word aangemoedig deur die stof te klassifiseer, verskille en ooreenkomste te ontdek, verhoudinge en patrone te bepaal, hoofgedagtes van minder belangrike feite te onderskei, nie feite en beginsels te verwar nie en op die logiese volgorde te let.

- Verskillende maniere kan ook aangewend word (byvoorbeeld weeklikse rapporte, groepsgesprekke, klastoetse en referate) om te sorg dat nuwe kennis goed met bestaande kennis geïntegreer word.

- Omdat Afrikastudente meestal prakties ingestel is, sal al die genoemde strategieë nog meer geslaagd wees indien dit vir hulle ook duidelik gemaak word wat die nut van selfstandige analitiese denke is, soos byvoorbeeld wanneer hulle eendag voltyds in 'n beroep staan en self besluite sal moet kan neem.

Aangesien daar 'n groot ooreenkoms tussen die denkwyse van Afrika en die Ooste is, kan hierdie onderwysstrategieë (asook dié van Bowen \& Bowen) heelwaarskynlik ook vrugbaar toegepas word op onderwys aan Oosterse studente. Hulle getalle neem ook in Suid-Afrika toe.

\subsubsection{Toepassing op eie bodem}

Heelwat navorsing ten opsigte van dink- en leerwyses is alreeds in Suid-Afrika gedoen. Dit kan maklik op die internet opgespoor word. Sulke navorsing is egter beperk tot antropologiese studies (vgl. byvoorbeeld Van Heerden, 1997) en veral psigologiese studies (waaronder byvoorbeeld dié van Engelbrecht, 1997; Van Niekerk, 1991; Lester, 2003 en Shochet, 1994).

Met hierdie bydrae op kultuur-filosofiese gebied, het die skrywer onder andere gepoog om 'n breër fundering te gee vir besinning oor onderrig wat kultureel relevant is - veral te midde van die transformasie wat tans in die tersiêre onderwys aan die gang is.

Vrae waaroor besin kan word, is onder andere die volgende: Is ons (tersiêre) onderwys nie té Westers georiënteerd, deur die leerproses eensydig as iets kognitiefs (teoreties-analities-krities) te beskou nie, in plaas daarvan om ' $n$ veel breër, holistiese leerproses te probeer bevorder nie? Is leer deur konkrete ervaring in die praktyk nie vir Afrikane en Oosterlinge kultureel meer relevant en vir alle kultuurgroepe ook noodsaaklik vir werklike beroepsbekwaamheid in die spesifieke (Suid-)Afrikaanse konteks nie? Moet karaktervorming nie as ' $n$ inherente deel van veral Christelike tersiêre onderwys beskou 
word nie? Die vraag behoort ook gestel te word of die gangbare (Westerse) definisie van akademiese uitnemendheid of standaarde ("excellence") kritiekloos aanvaar behoort te word. Is dit dus werklik so dat uitnemendheid en relevansie (vir byvoorbeeld die Afrikakonteks) mekaar by voorbaat uitsluit?

\section{Terugblik en perspektief}

In die begin van hierdie artikel is aangetoon dat kommunikasieprobleme op kognitiewe vlak hoofsaaklik as gevolg van diepgewortelde lewensbeskoulik-kulturele verskille ontstaan. Nadat die eie vertrekpunte vanwaaruit die vraagstuk benader sal word, uitgespel is, is vanuit kultuur-filosofiese hoek die denkwyses van die Ooste en Afrika met dié van die Weste vergelyk en oorsigtelik in Tabelle 1 en 2 saamgevat. Ten slotte is 'n praktiese toepassing op die gebied van die onderwys in Afrika gemaak. Al dié detail moet ten slotte weer in 'n breër perspektief geplaas word.

Kulture, as antwoord op God se skeppingsopenbaring, verskil omdat hulle neig om een basiese menslike verhouding te oorbeklemtoon die verhouding tot God/afgod, die natuur, die self en die medemens. As gevolg van die verskillende verhoudings wat klem ontvang, is verskillende gawes by sekere kulture sterker ontwikkel as by ander. Hierdie gawes sluit ook die kognitiewe gawes in - die kengawes waarmee mense die werklikheid probeer verstaan en sin daaruit maak. Kennis van die werklikheid kan egter op verskillende maniere verkry, verwoord en oorgedra word. 'n Mens weet meer as wat jy logies kan ken. Die verskillende kulture (Ooste, Afrika en die Weste) is daarvan 'n duidelike bewys.

"Om te leer ken" word selfs nie meer in die Weste eensydig beskou as die blote luister, lees, memoriseer en skryf nie. Gardner (1983) het meer as twintig jaar gelede alreeds aangetoon dat daar tussen verskillende soorte "intelligensies" (dalk eerder dink- en leerstyle) onderskei moet word. Nie slegs woord- en syfermense is "intelligent" nie, maar mense kan byvoorbeeld ook leer deur middel van visuele beelde, liggaamlike aksie, op 'n estetiese manier (musiek, dans, beeldende kunste), deur sosiale omgang en op tegniese wyse. Sulke andersoortige leerstyle beteken nie dat 'n persoon minder begaafd (intelligent) is nie, maar slegs anders begaafd is.

Olthuis (1997:6) beklemtoon in 'n boek Knowing other-wise:

Instead of judging that emotions are subversive of knowledge, or at best irrational urges that need to be controlled by reason, we believe emotions, as emotions, are vital and honourable ways of 
knowing. Feelings are themselves indispensable thermometers, signals registering how we apprehend, situate and motivate ourselves in engaging the world. There is also tactile-kinesthetic knowing as there is knowing a friend, and, to employ a Biblical idiom, knowing one's wife. In other words reasoning is only one of the ways in which we engage (i.e. know) die world.

Wat Olthuis (1997:6) hierna sê is baie belangrik:

Knowing is the multidimensional, embodied, gendered way human beings engage the world in order to situate themselves meaningfully (spiritually) and come close responsibly (ethically) to the different and other. We also know by touch, by feel, by taste, by sight, by sounds, by smell, by symbols, by sex, by trust - by means of every modality of human experience.

Nog belangriker is sy volgende woorde:

Knowing by thinking is no better, no worse, than any of the other modalities. Each modality, according to its own style, is an important and indispensable way in which we actively engage the world. In any human act of engagement, all the ways of knowing are reciprocally interwoven, simultaneously present, even when, as the case may be, one of the ways of knowing stands out and marks that particular activity in a heightened way (Olthuis, 1997:6).

Wat Gardner en veral Olthuis (laasgenoemde vanuit die modaliteitsleer van die Christelike filosofie van Dooyeweerd, Vollenhoven en Stoker) op sistematiese wyse verduidelik, is in hierdie artikel kultuur-filosofies aangetoon. Om God se skepping werklik te leer ken, het ons al die verskillende menslike vermoëns, funksies of modaliteite nodig en nie net die logies-analitiese nie. Omdat in sommige kulture verskillende van dié funksies sterker ontwikkel is - en selfs oorbeklemtoon word - as in ander, vestig hulle opnuut weer die aandag van 'n ander kultuur op dit wat hy verwaarloos het. Hierdie feit word deur 'n hele aantal skrywers vanuit verskillende vakgebiede geïllustreer in die resente versamelwerk Ways of knowing in concert onder redaksie van Kok (2005).

Wedersydse erkennende kulturele pluralisme word voorgestel as die antwoord op die probleem wat aan die begin van hierdie artikel gestel is. 'n Eng Eurosentriese, Oriëntalistiese of Afrosentriese oriëntasie is in die wêreld van die 21ste eeu nie meer gepas nie.

Behalwe wedersyds erkennend moet hierdie kulturele pluralisme egter ook wedersyds korrigerend wees. Indien dit in die lig van God 
se Woord kan geskied - wat elke kultuur transformeer - kan die resultaat nog ryker en meer bevrydend wees.

\section{Geraadpleegde bronne}

BOMAN, T. 1968. Das hebräische Denken im Vergleich mit dem griechischen. Göttingen: Vandenhoeck \& Ruprecht.

BOWEN, D.N. 1984. Cognitive styles of African theological students and the implication of these styles for bibliographic instruction. Ann Arbor: University Microfilms International.

BOWEN, E.A. 1984. The learning styles of African college students. Ann Arbor: University Microfilms International.

BOWEN, E.A. \& BOWEN, D.N. 1984. Mapping booklet: Cognitive style inventory for African students. Florida: Florida State University. (Unpublished manuscript.)

BOWEN, E.A. \& BOWEN, D.N. 1986. Theological education and learning styles in Africa. World Evangelical Fellowship Theological News, Jan.-Mrt.: 5-10.

BUCONYORI, E.A. 1991. Cognitive styles and the development of reasoning among younger African students in Christian higher education. Ann Arbor: University Microfilms International.

BUJO, B. 1998. The ethical dimension of community: The African model and the dialogue between North and South. Nairobi: Paulines Publications Africa.

DU PREEZ, P.H. 1976. 'n Ontleding van die Bantoe se dinkprosesse volgens Spearman se Wette. Pretoria: Benbo.

DU PREEZ, P.H. 1978. The psychology of the urban black: The gap between the tribe and the city. (In Marais, G. \& Van der Kooy, R., eds. South African urban blacks: Problems and challenges. Pretoria: Centre for Management Studies, UNISA. p. 75-97.)

ENGELBRECHT, P. 1997. Cultural variations in cognitive style: Field dependence vs. field independence. School Psychology International, 18(2): 155-164.

GARDNER, H. 1983. Frames of mind. New York: Basic Books.

GOLDSWORTH, G. 1995. Gospel and wisdom: Israel's wisdom literature in the Christian life. Carlisle: Paternoster.

GYEKYE, K. 1995. An essay on African philosophical thought: The Akan conceptual scheme. Philadelphia: Temple University Press.

GYEKYE, K. 1997. Tradition and modernity: Philosophical reflections on the African experience. New York: Oxford University Press.

HALL, E.T. 1981. The silent language. New York: Doubleday.

HALL, E.T. \& HALL, M.R. 1987. Hidden differences: Doing business with the Japanese. New York: Doubleday.

HALLEN, B. 1996. Analytical philosphy and traditional thought: A critique of Robin Horton. (In English, P. \& Kalumba, K.M., eds. African philosophy: A classical approach. New Jersey: Prentice Hall. p. 217-228.)

HIEBERT, P.G. 1998. Antropological insights for missionaries. Grand Rapids: Baker Book House.

HORTON, R. 1993. Paterns of thought in Africa and the West: Essays on magic, religion and science. New York: Cambridge University Press. 
HORTON, R. 1996. African traditional thought and Western science. (In English, P. \& Kalumba, K.M. African philosophy: A classical approach. New Jersey: Prentice Hall. p. 199-215.)

JARVIE, I.C. \& AGASSI, J. 1970. The problem of rationality in magic. (In Wilson, B.R., ed. Rationality: Key concepts in the social sciences. Oxford: Blackwell.)

KLAPWIJK, J. 1983. Rationality in the Dutch Neo-Calvinist tradition. (In Hart, H. e.a., eds. Rationality in the Calvinian tradition. Boston: University Press of America. p. 93-111.)

KLEM, H.V. 1982. Oral communication of the Scriptures. Insights from African oral art. Pasadena: William Carey Library.

KOK, J., ed. 2005. Ways of knowing in concert. Sioux Center: Dordt College Press.

LESTER, D. 2003. Assessment of thinking style preference and language proficiency for South African students whose native languages differ. Psychological Reports, 93(2):449-457.

NKEMNKIA, M.N. 1999. African vitalogy: A step forward in African thinking. Nairobi: Paulines Publications Africa.

NYASANI, J.M., ed. 1988. Philosophical focus on culture and traditional thought systems in development. Nairobi: Konrad Adenhauer Foundation.

NYASANI, J.M. 1997. The African psyche. Nairobi: Theological Printing.

O'DONOVAN, W. 2000. Biblical Christianity in modern Africa. Carlisle: Paternoster.

OLTHUIS, J.H., ed. 1997. Knowing other-wise: Philosophy at the threshold of spirituality. New York: Fordham University Press.

ONVLEE, L. 1973. Cultuur als antwoord. 's-Gravenhage: Nijhoff.

SHOCHET, I.M. 1994. The moderator effect of cognitive modifiability on a traditional undergraduate admissions test for disadvantaged black students in South Africa. South African Journal of Psychology, 24(4):208-215.

SOGOLO, G. 1993. Foundations of African philosophy: A definitive analysis of conceptual issues in African thought. Nigeria: Ibadan University Press.

SPENGLER, O. 1922-1923. Die Untergang des Abendlandes (2 dele). München: Beck.

STEYNE, D.M. 1989. Gods of power: A study of the beliefs and practices of animists. Houston: Touch Publications.

TARNAS, R. 1991. The passion of the Western mind: Understanding the ideas that have shaped our world view. New York: Ballantine Books.

VAN DER WALT, B.J. 2000. Visie op die werklikheid. Potchefstroom: Instituut vir Reformatoriese Studie.

VAN DER WALT, B.J. 2001. Afrocentric or Eurocentric? Our task in a multicultural South Africa. Potchefstroom: Institute for Reformational Studies.

VAN DER WALT, B.J. 2004a. Understanding and rebuilding Africa. Potchefstroom: The Institute for Contemporary Christianity in Africa.

VAN DER WALT, B.J. 2004b. 'n Skande- versus 'n skuldgeoriënteerde gewete: 'n verklaring vir die botsing tussen die Afrikakultuur en die Westerse kultuur? Koers, 69(1):29-55.

VAN HEERDEN, E. 1997. University education and African thought: Reflections on underachievement among some UNISA students. South African Journal of Ethnology, 20(2):76-85. 
VAN NIEKERK, H., ed. 1991. Cognitive development in South Africa. Pretoria: Human Sciences Research Council. (Occasional Papers, nr. 50.)

WIHER, H. 2003. Shame and guilt: A key to cross-cultural ministry. Bonn: Verlag für Kultur und Wissenschaft.

WILSON, M.R. 1997. Our father Abraham: Jewish roots of the Christian faith. Grand Rapids: Eerdmans.

WINCH, P. 1970. Understanding primitive society: The problem of the rationality of magic. (In Wilson, B.R., ed. Rationality: Key concepts in the social sciences. Oxford: Blackwell. p. 78-111.)

\section{Kernbegrippe:}

Afrikadenkwyse

Oosterse denkwyse

Westerse denkwyse

\section{Key concepts:}

African way of thinking Eastern way of thinking

Western way of thinking 